\title{
Forest Conservation Knowledge-Community Perception Within Protected Areas: The Case of Karagöl-Sahara National Park
}

\author{
Sevim Inanç \\ Artvin Çoruh University (Forestry Economy Department, Forestry Engineering, Artvin, Turkey
}

\begin{abstract}
Commitment of local communities to protected areas is essential for conserving forest and biodiversity. However, in many developing countries like Turkey, former management strategies kept human from protected areas using coercion. Fortunately, more recent regimes attempt to give local populations more control on the management but little is known about local residents' perceptions, beliefs and attitudes toward the management of these areas. This study, carried out around the Karagöl Sahara National Park, determined factors which support local communities' positive perceptions towards forest conservation in the park, analysed their assessment of current park management activities compared to former management approaches and draw the implications for effective participatory management of protected areas. We collected socio-demographic data from 100 residents on their awareness of conservation methods. The findings indicated that the positive behavior of local communities towards conservation of forest within Karagöl Sahara National Park was highly correlated with the current management strategy that involved more effectively local communities, the educational level of participants.

Participants' perceptions of forest conservation were strongly related to locally perceived benefits. Although 91 $\%$ of participants were favorable to the concept of forest and biodiversity conservation within the park. Our results suggested that understanding local residents' perceptions and using them as a starting point to improve the park-people relationship could help park management staff to involve more effectively local communities and improve their awareness about biodiversity conservation within the park.
\end{abstract}

Keywords- Karagöl-Sahara National Park, forest, IUCN, community conservation.

\section{INTRODUCTION}

Protected areas are the cornerstone of biological conservation. As defined by the International Union for Conservation of Nature (IUCN), protected area is a clearly defined geographical space, recognized, dedicated and managed, through legal or other effective means, to achieve the long-term conservation of nature with associated ecosystem services and cultural values (Dudley, 2008). One

basic objective of a system plan for protected areas is to effectively protect, develop and maintain representative samples of the various biotopes in the areas where they are installed (Abuzinada, 2003). Although protected areas have usually been set aside from human exploitation, it is now increasingly recognized that they should play a role in sustaining livelihood of adjacent local communities (Hamilton et al., 2000; Walpole and Goodwin, 2001; Charnley et al., 2007).

Responding to perceptions of many conservationists especially those working in poorer countries - that wildlife conservation and protected areas were doomed unless local communities become an integral part of conservation efforts (Hackel, 1999; Hamilton et al., 2000; Yeo-Chang, 2009), new strategies, often referred to as "community conservation" have evolved over the past two decades (Infield and Namara, 2001).

The "community conservation" approach seeks to accommodate local peoples' needs and aspirations by empowering them, promoting their active participation in local resource management, and improving their economic welfare (Songorwa, 1999; Infield and Namara, 2001; Mehta and Heinen, 2001).

To assess the effectiveness of these new park management policies for the long-term conservation of the park resources, it is important to gain insights into the factors that determine local communities' current positive perceptions about conservation of biodiversity within the park and their impressions relating to the park managers' activities. Following insights from previous research that local people perception is influenced by the type of management and the benefits they perceived from protected areas (Ormsby and Kaplin, 2005), we hypothesized that people who developed positive perception about Karagöl Sahara National Park and its biodiversity are those who get high benefits from the park. We also made the assumption that people who have positive opinion about the current park management methods developed positive perception about forest conservation within it. Based on preliminary results 
(Gillingham and Lee, 1999; Mehta and Heinen, 2001) and knowledge of cultural differences and gender in the area (Vodouhê et al., 2009), we also made assumption that local communities perceptions are function of their sex, origin, main activities, formal educational level and affiliation. The objectives of this study were to (1) determine factors which support local communities' current positive perceptions towards forest conservation in Karagöl Sahara National Park, and (2) analyse their assessment of current park management activities compared to former management approaches and draw the implications foreffective participatory management of protected areas.

\section{METHODS}

\subsection{Study area}

The location of Karagol-Sahara National Park and its immediate surroundings are shown in Figure 1. The research area was calculated by GIS techniques. This area is about 21,912 ha, and between 900 and $2700 \mathrm{~m}$ in altitude. Karagol-Sahara National Park covers 3466 ha area in this watershed. The area includes Ciritdüzü, Cevizli, Veliköy, Pınarlı, Meşeli, Yukarıkoyunlu, Aşağıkoyunlu, Köprülü, Kirazlı, Karakoy, Kocabey, Yavuzköy villages, kıfllas (low mountain pastures), and yaylas (high mountain pastures). There are many lakes, streams, mountains, and hills in the area.

In our study case, to identify factors which determine local residents' perceptions to conserve or not the forest and to manage the park, we used data related to participants' socioeconomic, demographic and perception towards forest conservation and park management.Our perception influences our attitude (Trakolis, 2001). Indeed, attitudes are formed in part bycommunities' and individuals' perceptions and experiences (Infield and Namara, 2001). The attitude itself can be considered an independent variable affecting behavior, however, and it can also affect the independent variable of motivation. In one sense, the attitude can also be considered an intervening variable since it is a derivative of motivation which determines behavior. We argue that people consider the implications of their actions before they decide to engage or not to engage in a given behavior (Ajzen and Fishbein, 1980). Therefore, knowing people's perceptions can produce useful information that could be incorporated into the decision-making process and lead to resolution of conflicts between local people and park authorities by improving attitudes and altering behavior.

\subsection{Household surveys}

Protected areas in developing countries are increasinglypopular destinations for wildlife tourists, and tourism has thepotential to generate sustainable local benefits, sufficient for localpeople to value, and therefore protect, their wildlife heritage as asource of incomeMost of the questions were closed-ended, although we includedsome open-ended questions to investigate participants' perceptiontowards forest conservation and park management. We alsorecorded data about participants' age, gender, profession, and educational level. We asked participantsabout their involvement in park activities, their link with localorganization in charge of park management, the benefits they obtainfrom park and their opinion on park management. We also collecteddata on participants' economic activities, their various sources ofincome and conservation awareness. in our study case, to identify factors which determinelocal residents' perceptions to conserve or not the forest andto manage the park, we used data related to participants' socioeconomic,demographic and perception towards biodiversity conservationand park management. These variables were identified inprevious studies as significant predictors of perceptions aboutconservation.

\section{RESULTS AND DİSCUSSIOON}

According to the survey data recorded in research field, socio demographic characteristics belong to local community are shown on Table 1 .

Table.1: Socio-demographic features of participant Gender

\begin{tabular}{l}
\hline Woman \\
\hline Man \\
\hline Total \\
\hline \multicolumn{1}{c}{ Age } \\
\hline $17-20$ \\
\hline $21-30$ \\
\hline $31-40$ \\
\hline $41-50$ \\
\hline $50+$ \\
\hline Total Marital Status \\
\hline Single \\
\hline Married \\
\hline Total \\
\hline \\
\hline Literate \\
\hline Primary Education \\
\hline Secondary Education \\
\hline Faculty \\
\hline Master- PhD \\
\hline Total \\
\hline Retired \\
\hline House wife \\
\hline Laborer \\
\hline Unemployed \\
\hline
\end{tabular}

Page | 3022 


\begin{tabular}{l} 
Officer \\
\hline Student \\
\hline Freelancer \\
\hline Total \\
\hline \multicolumn{2}{c}{ Level of income } \\
\hline to $1000 \mathrm{TL}$ \\
\hline between 1001 and 2000 TL \\
\hline between 2001 and 3000 TL \\
\hline over 3000 TL \\
\hline Total $\quad$ Family size \\
\hline between 1-3 \\
\hline between 4-6 \\
\hline Total
\end{tabular}

Table.2: Summary of the main questions of the questionnaire and some examples of answers.

\begin{tabular}{l}
\hline \multicolumn{2}{c}{ Some Qestions } \\
\hline Age, gender, education level, main \\
activity? \\
\hline Do you know the main objective of the \\
park? Yes/No \\
\hline Why was the park created? \\
Conservation/tourism/no opinion \\
\hline Importance of the presence of the park to \\
surrounding people? \\
Road maintenance/incomes \\
tourism/development \\
projects/infrastructure \\
Your expectation about the park \\
management? \\
More involvement of local people/more \\
land for agriculture/more revenue from \\
protected areas management
\end{tabular}

Our results suggest that people's positive perceptions of forestconservation were strongly influenced by their educationallevel and assessment about park management. Gender, age, family size had less influence.

These meaningful factors may be grouped into sociodemographiceducational level and perception factors (assessmentabout park management). Perceptions were relative to benefitsobtained from park due to the current management approach. Similarresults were found by Pyrovetsi and Daoutopoulos (1997) and Allendorf et al. (2006) who concluded thatindigenous people may express anti-environmental attitudes forvariety of reasons, including low education levels, lack of awarenessabout environmental issues and lack of participation.

Local communities also benefit frommany development projects and infrastructure due to the presenceof the park.
The findings clearly suggest that benefits are strongincentive for people to perceive conservation positively. Correlationbetween benefits and positive perception of biodiversity conservationhas been confirmed to be positively significant in many cases(Mehta and Heinen, 2001; Baral andHeinen, 2007). The improvement of benefits that local communitiesgot from the park will be a powerful incentive to increase theirwillingness about forest conservation within this area..

Educational level is one of the variables which affect people'sperception about forest conservation in the Karagöl Sahara NationalPark. All participants who are unfavorable to forest conservationhave a weak formal education level. This result supports thepositive link between consciousness about forest conservationand education showed by previous authors. Higher level ofeducation also helps to understand the role of the park and theusefulness of the conservation of its biological diversity. Anotherimportant reason which explains the relative high impact ofeducation on people's positive perception on forest is thatthose with good level of education rarely practice agriculture as theirmain activity. They are involved in non agricultural jobs such asteaching or working in local or national non government organizations.

Thus, they have less contact with park staff and resources.Although benefits obtained directly from the park are the mainfactor which improve people awareness about biodiversity conservation,those who originated from villages near the park alsosupported the existence of the park.

This finding appears to confirm surveys around parksin Turkey where people's agreement on the necessityto protect forest for future generations conduct them to developpositive attitudes about protected areas. The reference to future generation insupporting biodiversity and forest conservation is very important and needssupport from the park staff for more generalization. People who benefit from the Karagöl Sahara National Park, especially in terms of employment opportunities such as anti-poaching ranger and tourism guide, can hold more favorable attitudes towards the park, and extension of these benefits, in addition to locally relevant education, may have the greatest potential in shaping attitudes towards conservation.

The people's positive perception on park management isa good opportunity for biological diversity conservation. Previousstudies had showed that people's perceptions of the protected areasmanagement also strongly influenced their attitude about conservation.

Education is one of the factors which has positive impact on people perception of forest conservation. Education could be an important way to motivate people to develop

Page | 3023 
or reinforce positive perception about biodiversity conservation.

\section{REFERENCES}

[1] Abuzinada, A.H., 2003. The role of protected areas in conserving biological diversity in the kingdom of Saudi Arabia. Journal of Arid Environments 54, 3945.

[2] Allendorf, T., Swe, K.K., Oo, T., Htut, Y., Aung, M., Aung, M., Allendorf, K., Hayek, L.A., Leimgruber, P., Wemmer, C., 2006. Community attitudes toward three protected areas in Upper Myanmar (Burma). Environmental Conservation 33 (4), 344-352.

[3] Ajzen, I., Fishbein, M., 1980. Understanding Attitudes and Predicting Social Behaviour. PrenticeHall, New Jersey

[4] Baral, N., Heinen, J.T., 2007. Resources use, conservation attitudes, management intervention and park-people relations in the Western Terai landscape of Nepal. Environmental Conservation 34 (1), 64-72.

[5] Charnley, S., Fischer, A.P., Jones, E.T., 2007. Integrating traditional and local ecological knowledge into forest biodiversity conservation in the Pacific Northwest. Forest Ecology and Management 246, 14-28.

[6] Dudley, N., 2008. Guidelines for Applying Protected Area Management Categories.IUCN, Gland, Switzerland. $86 \mathrm{pp}$.

[7] Gillingham, S., Lee, P.C., 1999. The impact of wildlife-related benefits on the conservation attitudes of local people around the Selous Game Reserve, Tanzania. Environmental Conservation 26, 218-228.

[8] Hackel, J.D., 1999. Community conservation and the future of Africa's wildlife. Conservation Biology 13, 726-734.

[9] Hamilton, A., Cunningham, A., Byarugaba, D., Kayanja, F., 2000. Conservation in a region of political instability: Bwindi impenetrable forest, Uganda. Conservation Biology 14, 1722-1725.

[10] Infield, M., Namara, A., 2001. Community attitudes and behaviour towards conservation: an assessment of a community conservation programme around LakeMburo National Park, Uganda. Oryx 35 (1), 48-60.

[11] Mehta, J.N., Heinen, J.T., 2001. Does communitybased conservation shape favorable attitudes among locals? An empirical study fromNepal. EnvironmentalManagement 28, 165-177.

[12] Ormsby, A., Kaplin, B.A., 2005. A framework for understanding community resident perceptions of
Masoala National Park, Madagascar. Environmental Conservation 32 (2), 156-164

[13] Pyrovetsi, M., Daoutopoulos, G., 1997. Contrasts in conservation attitudes and agricultural practices between farmers operating in wetlands and a plain in Macedonia, Greece. Environmental Conservation 24 (1), 76-82.

[14] Songorwa, A.N., 1999. Community-based wildlife management (CWM) in Tanzania: are the communities interested? WORLD 27 (12), 20612079.

[15] Trakolis, D., 2001. Local people's perceptions of planning and management issues in Prespes Lake National Park, Greece. Journal of Environmental Management 61, 224-227.

[16] Vodouhê, G.F., Coulibaly,O., Greene, C., Sinsin, B., 2009. Estimating local values of non-timber forest products to Pendjari Biosphere Reserve Dwellers in Benin. Economic Botany 63 (4), 397-412.

[17] Walpole, M.J., Goodwin, H.J., 2001. Local attitudes towards conservation and tourismaround Komodo National Park, Indonesia. Environmental Conservation 28 (2),160-166.

[18] Yeo-Chang, Y., 2009. Use of forest resources, traditional forest-related knowledge andlivelihood of forest dependent communities: cases in South Korea. Forest Ecologyand Management 257, 2027-2034. 